\title{
Shelf Life Study and Antagonistic Activity of Trichoderma viride in Different Oil Formulations
}

\author{
L. Taral Akshata, D.D. Guldekar, S.R. Potdukhe, S.S. Kale and Ashwini Kumar*
}

Plant pathology section, College of Agriculture, Nagpur - 440010 (Maharashtra), India

Department of Plant Pathology, Jawaharlal Nehru Krishi Viswa Vidyalaya, Jabalpur-482004

(M. P.), India

*Corresponding author

\section{Keywords}

Trichoderma viride,

Paraffin oil,

Soybean oil, Liquid formulations

Article Info

Accepted:

04 October 2018

Available Online:

10 November 2018

\section{A B S T R A C T}

An investigation entitled "Evaluation of different oils on shelf life study of Trichoderma viride" was carried out during 2017-2018 in the department of Plant Pathology, College of Agriculture, Nagpur. Different oils viz., Paraffin oil, soybean oil, mineral oil, Potato Dextrose broth and talc was extensively used as carrier for Trichoderma viride. As compared to solid based carrier material the survival of Trichoderma viride in liquid based formulations is quite high and has the ability to limit the heat transfer high water holding capacity and maintain water around the cells for their metabolism. Shelf life studies clearly indicated significant differences at all the intervals. Population density of Trichoderma viride in the paraffin oil was $28.06 \times 10^{8} \mathrm{CFU} / \mathrm{ml}$ in the $1^{\text {st }}$ month whereas the population density of Trichoderma viride in the $6^{\text {th }}$ month was $18.33 \times 10^{8} \mathrm{CFU} / \mathrm{ml}$. It was found significantly superior over all other treatment. The effect on percent growth inhibition on Fusarium oxysporum f. sp. ciceri is 79.30 per cent on Rhizoctonia bataticola is 84.85 per cent and Sclerotium rolfsii is 79.14 per cent. It was recorded maximum in formulation containing paraffin oil it was found significantly superior over all the treatments. The effect of liquid formulations on spore germination of Trichoderma viride was also recorded the maximum spore germination are found in formulation containing paraffin oil after six months of storage.

\section{Introduction}

Trichoderma is a genus of asexually reproducing fungi that are often the most frequently isolated soil fungi; nearly all temperate and tropical soils contain 101-103 culturable propagules per gram. These fungi also colonize woody and herbaceous plant materials, in which the sexual Teleomorph (genus Hypocrea) has most often been found. They show a high level of genetic diversity, and can be used to produce a wide range of products of commercial and ecological interest. They are prolific producers of extracellular proteins, and are best known for their ability to produce enzymes that degrade cellulose and chitin-although they also produce other useful enzymes (Harman and Kubicek., 1998). Trichoderma is considered as most efficient biocontrol agents and have attracted considerable scientific attention as they are considered as promising alternative to 
chemical fungicides against many plant pathogens. Major mechanisms involved in the biocontrol activity of Trichoderma spp. are competition for space and nutrients, production of diffusible and/ or volatile antibiotics and hydrolytic enzymes like chitinase and $\beta-1,3-$ glucanase. These hydrolytic enzymes partially degrade the pathogen cell wall and leads to its parasitization (Navaneetha et al., 2015). Oil is used as carrier for liquid formulation. They are prepared by mixing the conidia harvested from the solid/ liquid state fermentation with a combination of vegetable/ mineral oils in stable emulsion formulation. In such formulations, microbial agents are suspended in a water immiscible solvent such as petroleum fraction (diesel, mineral oil), and vegetable oils (groundnut, etc) with the surfactive agent. This can be dispersed in water to form a stable emulsion. The oil used should not have toxicity to the fungal spores, plants, humans and animals. Such formulation of Trichoderma, Pseudomonas, Beauveria are now being used as foliar sprays. Oil-based formulations are supposed to be suitable foliar sprays under dry weather condition and to have prolonged shelf life (Ramanujam et al., 2010)

\section{Materials and Methods}

The present study was conducted in Plant Pathology Laboratory, College of Agriculture, Nagpur during the year 2017-2018.Pure culture of Trichoderma viride was collected from Plant Pathology Section, College of Agriculture Nagpur. The pure culture was mass multiplied for further studies.

\section{Oil base liquid formulation}

Mass multiplied Trichoderma viride was transferred in to mixing tank to harvest the spore and mycelium. Mixed Trichoderma viride formulation was poured into presterilized plastic bottles. Each treatment contained Glycerol (10ml), Dispersant $(1 \mathrm{ml})$, Surfactant $(3 \mathrm{ml})$, Suspender $(3 \mathrm{ml})$. Three oils are used viz., paraffin oil, soybean oil and mineral oil were incorporated into the Trichoderma viride formulation in each plastic bottles as per the given in treatments from $\mathrm{T}_{1}$ to $\mathrm{T}_{8}$. Whereas $\mathrm{T}_{9}$ was talc base departmental culture, $\mathrm{T}_{10}$ was liquid formulation market product. The bottles were packed with the help of caps and kept for a storage for six month at $27 \pm 1^{0}$ C. CFU count was under taken at monthly interval by serial dilution followed by pour plate method.

\section{Treatment details}

Each treatment contained with Glycerol $(10 \mathrm{ml})+$ Dispersant $(1 \mathrm{ml})+$ Suspender $(3 \mathrm{ml})$ + Surfactant $(3 \mathrm{ml})$

\section{Results and Discussion}

Effect of different liquid formulations on the shelf life of Trichoderma viride $(\mathrm{CFU} / \mathrm{ml})$ at various interval

It was revealed from the data that there were significant differences in Trichoderma viride at all the interval. The initial population of $T$. viride (Table 1) in first month was found maximum i.e. $28.06 \times 10^{8} \mathrm{CFU} / \mathrm{ml}$ in $\mathrm{T}_{1}$ (Trichoderma filtrate $(30 \mathrm{ml})+$ Paraffin oil $(53 \mathrm{ml})$ which was significantly superior over all treatments followed by $\mathrm{T}_{2}$ (Trichoderma filtrate $(20 \mathrm{ml})+$ Paraffin oil $(63 \mathrm{ml})$ where $26.40 \times 10^{8} \mathrm{CFU} / \mathrm{ml}$ was noticed in $1^{\text {st }}$ month. The observations recorded in the treatments $\mathrm{T}_{8}$ (24.63 x $\left.10^{8} \mathrm{CFU} / \mathrm{ml}\right), \mathrm{T}_{3}\left(24.56 \times 10^{8} \mathrm{CFU} / \mathrm{ml}\right)$ and $\mathrm{T}_{9}\left(20.16 \times 10^{8} \mathrm{CFU} / \mathrm{ml}\right)$ was also significantly superior. At the end of six months the maximum population density of $T$. viride was observed in $\mathrm{T}_{1}(18.33 \mathrm{x}$ $\left.10^{8} \mathrm{CFU} / \mathrm{ml}\right)$ which was followed by $\mathrm{T}_{2}(10.40$ x $\left.10^{8} \mathrm{CFU} / \mathrm{ml}\right), \mathrm{T}_{3}\left(5.46 \times 10^{8} \mathrm{CFU} / \mathrm{ml}\right)$ and $\mathrm{T}_{4}$ (3.06 x $\left.10^{8} \mathrm{CFU} / \mathrm{ml}\right)$. 


\section{Treatment Details}

\section{Treatment No.}

\begin{tabular}{|c|}
\hline $\mathrm{T}_{1}$ \\
\hline $\mathrm{T}_{2}$ \\
\hline $\mathrm{T}_{3}$ \\
\hline $\mathrm{T}_{4}$ \\
\hline $\mathrm{T}_{5}$ \\
\hline $\mathrm{T}_{6}$ \\
\hline $\mathrm{T}_{7}$ \\
\hline $\mathrm{T}_{8}$ \\
\hline $\mathrm{T}_{9}$ \\
\hline $\mathrm{T}_{10}$
\end{tabular}

\section{Treatment details}

Trichoderma filtrate $(30 \mathrm{ml})+$ Paraffin oil $(53 \mathrm{ml})$

Trichoderma filtrate $(20 \mathrm{ml})+$ Paraffin oil $(63 \mathrm{ml})$

Trichoderma filtrate $(30 \mathrm{ml})+$ Soybean oil $(53 \mathrm{ml})$

Trichoderma filtrate $(20 \mathrm{ml})+$ Soybean oil $(63 \mathrm{ml})$

Trichoderma filtrate $(30 \mathrm{ml})+$ Mineral oil $(53 \mathrm{ml})$

Trichoderma filtrate $(20 \mathrm{ml})+$ Mineral oil $(63 \mathrm{ml})$

Trichoderma filtrate $(30 \mathrm{ml})+$ PD broth $(53 \mathrm{ml})$

Trichoderma filtrate $(30 \mathrm{ml})+\mathrm{PD}$ broth $(63 \mathrm{ml})$

Departmental culture (Talc based)

Market product (liquid formulation)

Table.1 Effect of different liquid formulation on the shelf life of Trichoderma viride $\left(\times 10^{8} \mathrm{CFU} / \mathrm{ml}\right)$ at various interval

\begin{tabular}{|c|c|c|c|c|c|c|c|}
\hline \multirow{2}{*}{$\begin{array}{l}\text { Tr. } \\
\text { No. }\end{array}$} & \multirow[t]{2}{*}{ Treatment } & \multicolumn{6}{|c|}{ Month } \\
\hline & & I & II & III & IV & $\mathbf{V}$ & VI \\
\hline $\mathbf{T}_{\mathbf{1}}$ & $\begin{array}{l}\text { Trichoderma filtrate }(30 \mathrm{ml})+ \\
\text { Paraffin oil }(53 \mathrm{ml})\end{array}$ & 28.06 & 24.36 & 22.50 & 21.76 & 20.63 & 18.33 \\
\hline $\mathbf{T}_{2}$ & $\begin{array}{l}\text { Trichoderma filtrate }(20 \mathrm{ml})+ \\
\text { Paraffin oil }(63 \mathrm{ml})\end{array}$ & 26.40 & 22.80 & 19.76 & 21.20 & 12.40 & 10.40 \\
\hline $\mathbf{T}_{3}$ & $\begin{array}{l}\text { Trichoderma filtrate }(30 \mathrm{ml})+ \\
\text { Soybean oil }(53 \mathrm{ml})\end{array}$ & 24.56 & 21.20 & 11.56 & 10.70 & 7.70 & 5.46 \\
\hline $\mathbf{T}_{4}$ & $\begin{array}{l}\text { Trichoderma filtrate }(20 \mathrm{ml})+ \\
\text { Soybean oil }(63 \mathrm{ml})\end{array}$ & 13.13 & 12.23 & 11.36 & 10.10 & 6.43 & 3.06 \\
\hline $\mathbf{T}_{\mathbf{5}}$ & $\begin{array}{l}\text { Trichoderma filtrate }(30 \mathrm{ml})+ \\
\text { Mineral oil }(53 \mathrm{ml})\end{array}$ & 8.83 & 8.13 & 7.43 & 5.56 & 2.86 & 1.06 \\
\hline $\mathrm{T}_{6}$ & $\begin{array}{l}\text { Trichoderma filtrate }(20 \mathrm{ml})+ \\
\text { Mineral oil }(63 \mathrm{ml})\end{array}$ & 10.70 & 9.26 & 8.30 & 7.30 & 1.26 & 0.76 \\
\hline $\mathbf{T}_{7}$ & $\begin{array}{l}\text { Trichoderma filtrate }(30 \mathrm{ml})+ \\
\text { PD broth }(53 \mathrm{ml})\end{array}$ & 18.63 & 17.50 & 13.36 & 11.00 & 9.46 & 1.66 \\
\hline $\mathrm{T}_{8}$ & $\begin{array}{l}\text { Trichoderma filtrate }(20 \mathrm{ml})+ \\
\text { PD broth }(63 \mathrm{ml})\end{array}$ & 24.63 & 21.30 & 18.00 & 10.70 & 9.93 & 2.40 \\
\hline $\mathrm{T}_{9}$ & Departmental culture (Talc) & 20.16 & 17.43 & 16.43 & 13.23 & 12.83 & 2.23 \\
\hline $\mathbf{T}_{\mathbf{1 0}}$ & Market Product (liquid) & 10.6 & 7.96 & 6.96 & 4.46 & 3.60 & 0.96 \\
\hline & $\mathrm{F}$ test & Sig & Sig & Sig & Sig & Sig & Sig \\
\hline & $\mathrm{SE} \pm \mathrm{m}$ & 2.9 & 3.6 & 3.8 & 4.5 & 3.8 & 3.4 \\
\hline & $\mathrm{CD}(\mathrm{P}=0.01 \%)$ & 11.6 & 14.2 & 14.8 & 17.9 & 14.8 & 13.6 \\
\hline
\end{tabular}


Table.2 Effect of Trichoderma viride liquid formulations on per cent growth inhibition on $8^{\text {th }}$ DAI

\begin{tabular}{|c|c|c|c|c|c|c|c|}
\hline \multirow{2}{*}{$\begin{array}{l}\text { Tr. } \\
\text { No. }\end{array}$} & \multirow[t]{2}{*}{ Treatment } & \multicolumn{3}{|c|}{ Mycelial growth (mm) } & \multicolumn{3}{|c|}{$\%$ Growth inhibition } \\
\hline & & $\begin{array}{l}\text { Fusarium } \\
\text { oxysporum } \\
\text { f. sp. ciceri }\end{array}$ & $\begin{array}{l}\text { Rhizoctonia } \\
\text { bataticola }\end{array}$ & Sclerotiumrolfsii & $\begin{array}{l}\text { Fusarium } \\
\text { oxysporum } \\
\text { f. sp. ciceri }\end{array}$ & $\begin{array}{c}\text { Rhizoctonia } \\
\text { bataticola }\end{array}$ & Sclerotiumrolfsii \\
\hline$T_{1}$ & $\begin{array}{l}\text { Trichoderma filtrate }(30 \mathrm{ml}) \\
+ \text { Paraffin oil } 53 \mathrm{ml})\end{array}$ & 18.63 & 13.63 & 18.77 & 79.30 & 84.85 & 79.14 \\
\hline$T_{2}$ & $\begin{array}{l}\text { Trichoderma filtrate }(20 \mathrm{ml}) \\
+ \text { Paraffin oil }(63 \mathrm{ml})\end{array}$ & 21.23 & 16.43 & 21.67 & 76.41 & 81.74 & 75.92 \\
\hline $\mathbf{T}_{3}$ & $\begin{array}{l}\text { Trichoderma filtrate }(30 \mathrm{ml}) \\
+ \text { Soybean oil }(53 \mathrm{ml})\end{array}$ & 22.30 & 25.30 & 28.67 & 75.22 & 71.88 & 68.14 \\
\hline $\mathrm{T}_{4}$ & $\begin{array}{l}\text { Trichoderma filtrate }(20 \mathrm{ml}) \\
+ \text { soybean oil }(63 \mathrm{ml})\end{array}$ & 24.13 & 30.87 & 31.20 & 73.18 & 65.70 & 65.33 \\
\hline $\mathrm{T}_{5}$ & $\begin{array}{l}\text { Trichoderma filtrate }(30 \mathrm{ml}) \\
+ \text { Mineral oil }(53 \mathrm{ml})\end{array}$ & 33.38 & 43.64 & 43.60 & 62.91 & 51.51 & 51.56 \\
\hline$T_{6}$ & $\begin{array}{l}\text { Trichoderma filtrate }(20 \mathrm{ml}) \\
+ \text { Mineral oil }(63 \mathrm{ml})\end{array}$ & 34.67 & 42.67 & 43.36 & 61.47 & 52.58 & 51.82 \\
\hline $\mathrm{T}_{7}$ & $\begin{array}{l}\text { Trichoderma filtrate }(30 \mathrm{ml}) \\
+ \text { PD Broth }(53 \mathrm{ml})\end{array}$ & 35.27 & 37.57 & 41.57 & 60.81 & 58.25 & 53.81 \\
\hline$T_{8}$ & $\begin{array}{l}\text { Trichoderma filtrate }(20 \mathrm{ml}) \\
+ \text { PD Broth }(63 \mathrm{ml})\end{array}$ & 33.00 & 41.77 & 43.00 & 63.33 & 53.58 & 52.22 \\
\hline $\mathbf{T}_{9}$ & Departmental culture (Talc) & 25.16 & 32.43 & 40.30 & 72.03 & 63.97 & 55.22 \\
\hline \multirow[t]{5}{*}{$\mathbf{T}_{10}$} & Market Product(liquid) & 42.93 & 38.97 & 43.67 & 52.30 & 56.70 & 51.48 \\
\hline & Control & 90.00 & 90.00 & 90.00 & 100 & 100 & 100 \\
\hline & F test & Sig & $\mathrm{Sig}$ & Sig & & & \\
\hline & $\mathrm{SE} \pm \mathrm{m}$ & 0.65 & 0.59 & 0.83 & & & \\
\hline & $\mathrm{CD}(\mathrm{P}=0.01 \%)$ & 2.55 & 2.31 & 3.24 & & & \\
\hline
\end{tabular}


During the shelf life study Reddy et al., (2017) calculated that $T$. harzianum in the form of CFU on $56^{\text {th }}$ day of observation paraffin oil $\left(20 \times 10^{7}\right)$ and in soybean oil (2.1 $\mathrm{x} 10^{7}$ ) gave the best result of spore viability. Nadare et al., (2018) revealed that the colony forming unit of Trichoderma viride were maximum in paraffin oil which was followed by soybean oil. Sathiyaseelan et al., (2009) showed that application of paraffin oil increases the shelf life of Trichoderma which was used as a bio fungicide comparing to liquid formulation of Trichoderma was more effective to control phytopathogen.

Effect of Trichoderma viride liquid formulation on per cent growth inhibition on $8^{\text {th }}$ DAI

All the treatments significantly inhibited the radial mycelial growth of Fusarium oxysporum f. sp. ciceri, Rhizoctonia bataticola and Sclerotium rolfsii over control. Observations recorded in Table 2 showed that treatment $\mathrm{T}_{1}$ (Trichoderma filtrate $(30 \mathrm{ml})+$ Paraffin oil (53ml)) was found significantly superior to the rest of treatments in checking the growth of Fusarium oxysporum f. sp. ciceri. It showed $18.63 \mathrm{~mm}$ mean colony diameter against the control $(90 \mathrm{~mm})$ with per cent inhibition of 79.30 at $8^{\text {th }}$ DAI, respectively it was followed by the treatment $\mathrm{T}_{2}$ (Trichoderma filtrate $(20 \mathrm{ml})+$ Paraffin oil $(63 \mathrm{ml}), \mathrm{T}_{3}$ (Trichoderma filtrate $(30 \mathrm{ml})+$ Soybean oil (53ml)) andT 4 (Trichoderma filtrate $(20 \mathrm{ml})+$ Soybean oil $(63 \mathrm{ml}))$ with mean mycelial growth of the organism 21.23 $\mathrm{mm}$ in $\mathrm{T}_{2}, 22.30 \mathrm{~mm}$ in $\mathrm{T}_{3}, 24.13 \mathrm{~mm}$ in $\mathrm{T}_{4}$, with per cent inhibition of 76.41 in $\mathrm{T}_{2}, 75.22$ in $\mathrm{T}_{3}, 73.18,65.70$ in $\mathrm{T}_{4}$ respectively in Fusarium oxysporum f. sp. ciceri.

In Rhizoctonia bataticola $\mathrm{T}_{1}$ (Trichoderma filtrate $(30 \mathrm{ml})+$ Paraffin oil $(53 \mathrm{ml})$ is significantly superior to rest of the treatments. The mycelial growth of $\mathrm{T}_{1}$ over the control
$(90 \mathrm{~mm})$ was 13.63 with per cent inhibition 84.85 at $8^{\text {th }}$ DAI. $\mathrm{T}_{1}$ was followed by $\mathrm{T}_{2}, \mathrm{~T}_{3}$ and $\mathrm{T}_{4}$ showed $16.43,25.30$ and 30.87 with per cent inhibition $81.74,71.88$ and 65.70 showed in Table 2.

In case of Sclerotium rolfsii $\mathrm{T}_{1}$ (Trichoderma filtrate $(30 \mathrm{ml})+$ Paraffin oil $(53 \mathrm{ml}))$ treatment is significantly superior over control $(90 \mathrm{~mm})$ mean colony growth 18.77 with per cent inhibition 79.14 followed by $T_{2}, T_{3}$ and $T_{4}$ with mean colony mycelial growth were 21.67, 28.67 and 31.20 per cent inhibition $75.92,68.14$ and 65.33 showed in Table 2). The present investigation are in accordance with the results of earlier workers like Rajput et al.,(2010), Siameto et al., (2010), Perveen et al., (2012), Srivastava et al., (2012), Tapwal et al., (2015), Dixit et al., (2015) showed that the bioagent like Trichoderma viride inhibit the mycelial growth of the soil born pathogen. They revealed that the maximum growth reduction in the Fusarium oxysporum f. sp. ciceri, Rhizoctonia bataticola. Perveen et al., (2012) showed that the antagonistic activity of Trichoderma viride against Fusarium oxysporum was excellent. Similar results were also obtained by Siameto et al., (2010) and Srivastava et al., (2012), Seema and Devaki (2012).

\section{Acknowledgement}

Authors are thankful to Professor and Head, Department of Plant Pathology, College of agriculture Nagpur for providing facilities for conducting the present research work.

\section{References}

Harman, G. E. and C. P. Kubicek, 1998. Trichoderma and Gliocladium, Vol. 2. Enzymes, Biological Control and Commercial Applications. Taylor and Francis, London, UK. 
Nadare, M., D. D. Guldekar, S. R. Potdukhe and J. M. Parbat, 2018. Assessment of shelf life of Trichoderma viride on different liquid formulations. Int. J. Curr. Microbiol. App. Sci. (6): 25752579.

Navaneeetha, T., R. D. Prasad and V. L. Rao, 2015. Liquid formulations of Trichodema species for management of Grey mold in Castor (Ricinus cumunis $L$.$) and Alternaria leaf blight in$ Sunflower (Helianthus annuus L.). J. Biofertil. Biopestici. 6(1): 149.

Perveen, K. and N. A. Bokhari, 2012. Antagonistic activity of Trichoderma harzianum and Trichoderma viride isolated from soil of date palm field against Fusarium oxysporum. Afr. J. of Microbiol. Res. 6(13): 3348-3353.

Rajput, V. A., S. A. Konde and M. R. Thakur, 2010. Evaluation of Bioagents against chickpea wilt complex. J. Soil and Crops. 20(1) 155-158.

Ramanujam, B., R. D. Prasad, S. Sriram and R. Rangeswaran, 2010. Mass production, formulation, quality control and delivery of Trichoderma for plant disease management. The J. of Pl. Prot. Sci. 2(2): 1-8.
Reddy, D. S., N. Haritha and M. P. Latha, 2017. Antagonistic activity and shelf life study of Trichoderma harzianum (Rifai). Int. J. Curr. Microbiol. App. Sci. 6(7): 2611-2615.

Sathiyaseelan, K., P. Sivasakthivelan and G. Lenin, 2009. Evaluation of a antagonistic activity and shelf life of Trichoderma viride. Boty. Res. Intern. 2(3):195-197.

Seema, M. and N.S. Devaki, 2012. In vitro evaluation of biological control agents against Rhizoctonia solani. J. of Agril. Tech. 8(1): 233-240.

Siameto, E.N., S. Okoth, N. O. Amugune, and N. Chege, 2010. Antagonism of Trichoderma harzianum isolates on soil born plant pathogenic fungi from Embu District Kenya. J. of yeast and fungal Res. 1(3): 47-54.

Srivastava, M., A. Singh and M. Shahid, 2012. In vitro growth performance of Trichoderma species and antagonistic activity against soil borne pathogens. Int. J. of Sci. and Res. 3(7): 672-675.

Tapwal, A., G. Thakur, S. Chandra, 2015. In vitro evaluation of Trichoderma species against seed borne pathogens. IJCBS Res. Pap. 2349-2724.

\section{How to cite this article:}

Taral Akshata, L., D.D. Guldekar, S.R. Potdukhe, S.S. Kale and Ashwini Kumar. 2018. Shelf Life Study and Antagonistic Activity of Trichoderma viride in Different Oil Formulations. Int.J.Curr.Microbiol.App.Sci. 7(11): 225-230. doi: https://doi.org/10.20546/ijcmas.2018.711.028 